\title{
24
}

\section{UNDERSTANDING STATE CRIME}

\author{
Penny Green and Tony Ward
}

With a few honorable exceptions, criminology has ignored a simple truth about crime

- that serious crime is predominantly committed by states and their officials. State crimes are generally easy to recognize: genocide (though rarely in the early stages), war crimes, torture, police violence, and 'grand corruption' - the organized plunder of national resources by a ruling elite. Other forms of state crime, however, are less recognizable: forced eviction, land grabbing, the avoidable effects of many natural disasters. The framework that we offer in this chapter seeks both to provide the conceptual tools to enhance 'recognition' and to explain state crime in a way that relates it to the disciplinary concerns of criminology while drawing on the contributions of other disciplines.

The questions asked by scholars of state crime are essentially those major political and sociological concerns that have informed critical criminology for at least four decades and relate to the exercise of governance and abuse of power by state agents; the relationship between state, capital and crime; class, gender and ethnic relations and conceptions of justice and the challenge to state power from below. These concerns, however, have not been addressed exclusively by scholars who would embrace the label 'critical'. For example a great deal of mainstream policing scholarship is concerned with abuses of state power and cannot avoid engaging with issues of class, even if not in the (neo-)Marxist spirit that pervades much of the overtly critical literature (see for example Hinton and Newburn 2009; Punch 2012, 
2013). What distinguishes critical criminology is its central concern with demystifying state-defined conceptualisations of crime as a highly selective, class based censure of social harms. Critical criminology made clear in the 1980s that the harms of the powerful far outweighed the harms of the powerless, and that the criminal label was often employed by the state as a weapon against those sections of society which challenged it or its corporate allies. It took some time, however, before scholars committed to theorising state criminality and even longer before empirical investigations into state deviance were to be conducted on a serious and global scale.

We are now witnessing a surge in scholarship that seeks to apprehend, interpret and expose the orchestrated harms of states and corporations (and often the confluence of both) as crimes. This has involved the repositioning of traditional representations of the protagonists - so that conventional conceptions of the state as 'protector' against, and victim of, crime are replaced by, or combined with, the often more accurate representation of the state as perpetrator of crime. Sophisticated, challenging and courageous methodologies now provide an increasingly powerful evidence base for state crime scholarship.

We begin this chapter by discussing the vexed question of how to defined state crime. We then discuss the extent of plainly criminal state activity in today's world, before considering various approaches to the explanation of state crime and the methods by which criminologists can study it.

defining state crime

The notion of state crime raises some obvious definitional problems. First, what is a state? As Weber (1970) famously argued, states claim a monopoly of the legitimate 
use of force in their territory. Unpacking this definition, we can say that a state is an organization that both exercises, if not a monopoly, at least dominance over the use of organized force within some significant territory, and lays claim to political legitimacy. By these criteria, the 'so-called Islamic State' is indeed a state, and a criminal one.

Like the study of corporate crime, state crime scholarship imputes criminal acts and intentions to group agents (List and Pettit 2011): groups of people whose actions are coordinated to achieve shared goals, in ways which presuppose the truth of certain beliefs about the world. States are complex and internally differentiated, and while in certain contexts they may be regarded as single agents it is often more realistic to impute acts and intentions to specific state agencies without supposing that they are shared by the state as a whole (ibid.: 40). Group agents may be nested one within another - a particular police squad may have shared beliefs and goals but may (or may not) also act in concert with other units to achieve the goals of the force as a whole. At times, and particularly in times of crisis (e.g. the UK miners' strike: Green, 1998) so many state agencies may be acting in a coordinated way that it is reasonable to treat 'the state' as a single group agent.

What, then, is state crime? In this chapter we adopt a definition we have advocated elsewhere (Green and Ward 2000, 2004): it is organizational deviance, by state agencies (in the sense just explained), which violates human rights. As Robert Agnew observes, our definition attempts to 'integrate the essentialist and constructionist perspectives' on crime (Agnew 2011: 29). The 'essentialist' element is an assumption that some acts are objectively harmful to human beings, and that human beings have prima facie moral rights not to be harmed in those ways. We can leave aside philosophical arguments about whether the existence of human rights is an 
objective moral reality: it suffices to say that we (and, we hope, most criminologists) have a moral commitment to certain basic rights that we think states ought to respect. We can also leave aside Agnew's view, shared by some state crime scholars (e.g. Rothe 2009), that international law provides an 'objective' definition of harmful behaviour. International human rights instruments do a reasonable job of categorising the sorts of harm with which we are concerned (torture, deprivation of liberty, denial of essential health care, etc.), but understanding the basic needs or interests of human beings as creatures capable of agency is not a matter in which social scientists need to defer to the law (see Doyal and Gough 1981).

The 'constructionist' perspective on crime emphasizes that it is behaviour that is seen as harmful and wrong by the state and/or some significant social audience. In the nature of state crime, it is typically not 'labelled' or censured as culpable behaviour by the state itself. This labelling or censuring role is primarily played, rather, by a range of organizations that make up 'civil society': associations independent of the state with some capacity for formulating or advocating norms of conduct and disseminating information about their violation. The term 'civil society' is broad enough to cover international NGOs like Amnesty, local grass roots organizations, media outlets independent of the state, and religious bodies. Civil society can exist, and effectively censure and resist state crimes, even in repressive states that offer it little or no legal protection (Beyerle 2014: 16-17). ${ }^{1}$

\footnotetext{
${ }^{1}$ This aspect of civil society was the subject of a research project by the authors and colleagues at the International State Crime Initiative: 'State Crime and Resistance: A Comparative Study of Civil Society' funded by Economic and Social Research Council grant no ES/I030816/1 (see Green and Ward, forthcoming).
} 
Some state crime attracts formal, legal censure from bodies such as the International Criminal Court, but this is comparatively rare (23 cases at the ICC up to the time of writing), and to confine our attention to these cases would be to take a very narrow view of state crime. The selection and processing of cases by international tribunals is, however, a fertile field for criminological inquiry (see e.g. Hagan 2003, Mullins 2011).

Agnew (2011) offers his own combination of 'essentialist' and 'constructivist' perspectives which brings state crime within a comprehensive definition and classification of crimes. He proposes that criminologists should rank actions according to the degree to which they (1) amount to blameworthy harms, i.e. harms inflicted intentionally, recklessly or negligently and without justification or excuse; (2) are condemned by significant sections of the public; and (3) are subject to state sanctions. Acts which meet any of these criteria to a significant degree fall within the scope of criminology, but 'core crimes', the paradigmatic subject-matter of conventional criminology, rank high on all three. Agnew's approach resembles ours inasmuch as he combines a human-rights based definition of harm with a recognition that either the state or the public may censure behaviour as harmful and blameworthy. He refers to both Kauzlarich and Kramer's (1998) and our own (Green and Ward 2004) work on state crime as examples of how criminologists might elaborate on the classification of crime that he offers. In this spirit, we would like to suggest that the most serious forms of state crime fall into a category not clearly recognized in Agnew's own work. What may be termed 'core state crimes' are identical to Agnew's 'core crimes' - murder, rape, theft, etc., - except that, while clearly harmful, blameworthy, widely condemned and in most cases illegal, they carry little risk of a state-imposed sanction, at least in the short term. These 'core' crimes should be 
distinguished - even if the dividing line is blurred - from, for example, 'the intersection of global warming, governmental action - or inaction - and corporate behaviour in ways that produce state-corporate crimes of global warming' (Lynch and Stretesky 2010: 71). Without questioning that this is an immensely important category of harm and of legitimate interest to criminologists, we do question whether it is helpful to equate it with genocide (ibid: 72). Core state crimes and ambiguously criminal state harms call for different kinds of analysis. We turn to the analysis of core crimes in the next section, but for reasons of space will touch only briefly on more ambiguous cases.

\section{THE MODERN CRIMINAL STATE}

State crime is ubiquitous. In 2014 Amnesty International recorded human rights violations in 160 of the world's 196 states and territories and documented torture in 131 of them.

We are all familiar with the 'core' crimes committed by states, even if we haven't constructed them as such: the ongoing genocides in Sudan's Darfur region and Burma's Rakhine state; the Israeli bombing of Gaza in 2014; the US torture of Iraqi prisoners in Abu Ghraib; the brutality of Ben Ali's Tunisian police state; the terror and corruption of the Egyptian ruling elite represent some of the more egregious acts of state crime. The scale of state killing and systematic theft by ruling elites is staggering and the organized and planned criminality of governments has resulted in immeasurable pain and suffering. Yet the shroud of secrecy, official resistance, and an ideological/juridical culture which confines hegemonic understandings of criminality to the actions of the powerless results in an absence of state crime statistics, a misplaced sense of public fear, and a resistance within criminology to invoking the 
state as perpetrator. Even for those crimes acknowledged in international lawtorture, genocide, crimes against humanity, and war crimes-governments have shown at best only a selective interest in monitoring and measuring. There is no doubt that impunity, secrecy, and a lack of political will impose enormous challenges to the accurate recording of state criminality.

The few attempts there have been to quantify the scale of state crime are inevitably challenged by these complexities. R.J. Rummel, nonetheless, has calculated that 262 million people died between 1900 and 1999 through the 'murder of any person or people by a government including, genocide, politicide and mass murder' (Rummel n.d.). While the great majority of these murders (around 85\%) occurred in China (under both Communist and Nationalist regimes), the USSR, the Third Reich and the colonies of the European powers, there are numerous other regimes who contributed at least hundreds of thousands of deaths to the century's record of carnage.

There have been a number of more recent attempts to quantify the state murder of civilians in individual conflicts. One of the most notable is that conducted by the NGO, Iraq Body Count (2011). They estimated that state, militia, and insurgent killing resulted in between 99,704 and 108,856 violent deaths of civilians in Iraq between the 2003 invasion and January 2011. When the Wikileaks Iraq War Logs data on 15,114 new civilian deaths is added, the total figure of estimated civilian deaths rises to 123,960 (www.iraqbodycount.org/analysis/numbers/warlogs/). The Syrian Center for Policy Research has calculated that since the beginning of the war in 2011, 470,000 Syrians have been killed (SCPR 2016) and according to the Syrian Network for Human Rights (whose estimated death toll of civilians between March 20111 and November 2015 was 180,879) 95\% were victims of President Bashar Al 
Assad's forces. In the course of Israel's 'Operation Cast Lead' 23 day bombardment of Gaza between December 272008 and January 18, 2009, approximately 1,440 Palestinians were killed (over half estimated to be civilians), compared with 13 dead (including four civilians) on the Israeli side (Congressional Research Centre 2009).

Mary Kaldor identifies human rights violations and war crimes (that is state crimes) as 'a central methodology' of modern armed conflict where politics frames rather than determines the 'violent enterprise' (Kaldor 2006:121-2). Instead of isolated actions of criminal soldiers or military units, crimes of war now extend to the core of modern armed conflict and are fuelled by looting, illegal trading in diamonds, minerals and timber, corruption, and transnational criminal networks (Green and Ward 2004). Moreover, as Kaldor observes, 'we have good and accurate statistics for the deaths of men in state-based uniforms, but information about the vast majority of victims is totally inadequate' (Kaldor 2013:9)

If we combine these few attempts to quantify the scale of state crime with the vast and increasing body of work by human rights NGOs, journalists and academics from a range of disciplines it is clear that state violence and corruption can no longer be left in criminology's hinterlands - rather, state crime should be central to any adequate definition of the scope of criminology.

According to the World Health Organization (WHO) in 2000 some 310,000 people were killed as a result of collective or war-related violence (2002: 10); this represented 20 per cent of all global violent deaths at the time. The WHO acknowledges that this figure, which excludes domestic deaths at the hands of police and security forces, is the tip of an iceberg given the secrecy and denial which envelops so much state violence. One measure of the states' capacity for violence is military expenditure. Evidence from the Stockholm International Peace Research 
Institute (SIPRI 2015) suggests that in 2014 world military expenditure (estimated at $\$ 1776$ billion) represented 2.3 percent of world GDP. While overall global military spending declined by 0.4 percent between 2013-14 this was largely a function of decisions in the US, South America and Europe. China, Russia and Saudi Arabia all increased military expenditure substantially during the period (SIPRI 2015).

Of course, not every death in war is the result of a war crime; the very idea of a war crime presupposes that some killing in war is lawful. Ruggiero (2005) has argued for a pacifist criminology that would treat war itself as criminal. Such an approach would, however, ignore the very significant differences in the degrees to which states and insurgent forces seek to conduct their operations in a lawful manner. For example, ongoing research by Alicia de la Cour Venning ${ }^{2}$ explores the apparent adoption of IHL norms by Myanmar's armed ethnic Kachin Independence Army in its long-running war with the Myanmar state. She seeks to determine how the adoption of these norms, within the context of an armed conflict, can be conceptualized as an effective strategy for challenging a criminal regime. The Myanmar state's criminality is relevant as it characterizes the context within which the KIA must make decisions. Her research has the potential to extend state crime theory by investigating the extent to which compliance with international humanitarian norms impacts effective strategies of resistance to prolonged and brutal state criminality.

\footnotetext{
${ }^{2}$ De La Cour Vening (2016) unpublished doctoral research, 'To what extent do Kachin Independence Army perceptions of international humanitarian norms conform with development of its policies and practice?' ( Queen Mary University of London)
} 


\section{EXPLAINING CORE STATE CRIME}

Brannigan (2013) highlights three features of genocide and similar mass atrocities that criminology needs to explain. The first of these 'paradoxes' is that atrocities are committed for the most part by 'ordinary men' (Browning 1998), and sometimes by ordinary women (see e.g. Sharlach 1999), in the absence of psychopathology, acute provocation or duress. The second is that although most of these actions are recognized by national and international law as grave crimes, they are or have been 'conventionalized', that is, they remain technically proscribed but are rarely punished (Carson 1979; Brannigan 2013: 32-3). It is this feature that chiefly distinguishes 'core state crimes' from 'core crimes' in Agnew's sense, which attract severe state sanctions as well as public disapproval. The third 'paradox' is that the enormous 'dark figure' of state-instigated violence eclipses that of serious 'street' crime and yet it has received far less attention from criminology.

Faced with these paradoxes, there are two ways that an attempt at criminological explanation can go. One is to suggest that atrocities are not, after all, so very different from other core crimes. In very broad and abstract terms, the same kinds of criminogenic factors are present: motivation, opportunity and an absence of effective control. What has to be taken into account in analysing state crimes is that these factors operate on several different organizational levels as well as the level of the individual perpetrator. This approach has been developed most systematically in the 'integrated theory' which underpins much of the state crime scholarship of the last two decades, especially in the USA (Kauzlarich and Kramer 1998; Mullins and Rothe 2008). An analysis by Hoofnagle (2011) of mass murder and rape in Burundi provides a typical example of this approach. She identifies motivational drives such as international economic policies; opportunities afforded by a chaotic situation, coupled 
with unclear lines of command in the military; some limited constraint on the violence provided, albeit haphazardly, by international peacekeeping efforts; and some mechanisms of control, i.e. would-be deterrent measures taken after the event, which were not implemented effectively. While accounts such as this encapsulate a variety of causal factors in a way that is easily assimilated to mainstream criminological theory, they are open to criticism for being essentially descriptive and offering limited insight into any deeper and less easily legible process that might underlie the surface phenomena (Lasslett 2010). The use of parallels with 'street' crime is perhaps most productive when it yields insights into the emptional and interpersonal dynamics of extreme violence, as in Rafter's (2016) recent work on genocide.

Another response to Brannigan's 'paradoxes' is to emphasise that core state crime is fundamentally different from other crimes by reason of its essentially conformist, rather than deviant, nature. In the phrase coined by Kelman and Hamilton (1989), they are 'crimes of obedience'. As Smeulers puts it:

a crime qualifies as a crime of obedience when it is supported by the authority structure... This very fact turns the whole analytical framework which underlies criminological theory upside down ....[W]e have to focus on the question why [the perpetrators] are obedient, why they followed the group, why they do live by the (deviant and immoral) rules. (Smeulers 2008: 236-7).

Talk of 'deviant rules', however, raises the question as to whether this is really a complete inversion of mainstream criminology, rather than a variant of differential association theory. After all, employees of dishonest corporations and members of mafia-like organizations might also be said to live by deviant rules.

The classic study of immoral obedience to authority is Milgram's (1974) notorious series of experiments (partially replicated by Burger 2009) in which a 
majority of subjects were prepared to inflict what they were told were high-voltage electric shocks on another participant (in reality an actor). What can be learnt from Milgram's seriously flawed and unethical experiments is a highly controversial question (Brannigan 2013, Russell and Gregory 2015). The artificial setting in which subjects were confronted with unexpected demands under the direct supervision of an authority figure (a white-coated 'scientist') cannot be considered a realistic model for the position of state-appointed torturers and murderers who must carry out extreme violence repeatedly over long periods, often without direct supervision.

While highly critical of Milgram's use of his findings to explain the Holocaust, Brannigan (2013) is also in the camp that sees mass atrocities in terms of conformity rather than deviance. Brannigan draws on the work of Elias (2000 [1939]) who related the monopolization of violence by European states since the middle ages to changing sensibilities regarding violence in everyday life. Although the relation between the two is not simple or direct, the concentration of legitimate violence in the hands of the state has developed hand-in-hand with the 'civilizing process' of increasing self-restraint by individuals in the exercise of violence and other bodily functions such as eating and sex. Brannigan argues that modern genocide must be understood as the actions of individuals who are 'civilized' in this sense. He disagrees with Elias's (1987) suggestion that Nazi Germany witnessed a partial regression to 'barbarism'. Germany remained, he argues, a thoroughly controlled and, in Elias's sense, a 'civilized' society; and the more recent genocide in Rwanda also occurred in the context of a tightly controlled, bureaucratic state. Brannigan sees genocidal behaviour as a form of deviance resulting from an excess, rather than a deficit of 
control, paralleling Durkheim's 'altruistic' and 'fatalistic' forms of suicide. ${ }^{3}$ There is a kind of altruism and the perpetrators' sense of duty and commitment to the genocidal ideology of the state, and a kind of fatalism in the willingness to persist in genocide even in the face of inevitable defeat.

Our own analysis of state violence (Green and Ward 2007, 2008) shares Brannigan's debt to Elias but sees an important truth in Elias's view that there are 'decivilizing' counterflows at work within the 'civilizing process'. Along with subjection to the state comes a licence to use violence creatively and autonomously in pursuit of the state's goals. De Swaan's (2001) concept of enclaves of barbarism captures this synthesis within an Eliasian perspective. For de Swaan, the key feature of the 'bureaucratization of barbarism' is the comparmentalization of the target population, the sites of torture or murder, the roles of the perpetrators, and their emotional experiences:

wildness and brutality are let loose, or maybe even instilled, and at the same time instrumentalized, for specific purposes, within demarcated spaces at an appointed time: an archipelago of enclaves where cruelty reigns while being reined in all the while.... [T] he regime creates and maintains compartments of destruction and barbarism, in meticulous isolation, almost invisible and well-nigh unmentionable (de Swaan 2001: 269).

Within these 'enclaves', including the Nazi concentration camps and the sites of mass slaughter in Rwanda, what takes place is not simply routinized, efficient killing but a wide variety of acts of extreme cruelty that go well beyond dutifully carrying out

\footnotetext{
${ }^{3}$ In Durkheim's explanatory scheme, altruistic suicides (driven by duty and self-sacrifice), derive from deficient individuation, while fatalistic suicides, such as those of slaves, derive from an excess of regulation (Durkheim, 1952: 217-21, $276 \mathrm{n}$.).
} 
orders and owe much of their social meaning to their 'excessive' character (see for example African Rights, 1994; Sofsky, 1997).

The contradiction between 'civilized' sensibilities (in Elias's sense) and the demands of the violent state is manifested most acutely when extremely repressive policies take roots in states that have experienced relatively liberal forms of democratic political rule. States of this kind have been the subject of several exemplary studies, including Schirmer's (1998) of the Guatemalan military in the 1980s, Huggins' work on Brazilian torturers and murders (Huggins et al. 2002), Haritos-Fatouros' $(1988,2003)$ and Gibson's (1990) work on torture under the Greek junta, and the work of Feitlowitz (1998), Marchak (1999), and others on Argentina.

Whilst there are many nuances and regional particularities, we can identify a number of general explanatory themes in this body of scholarship. The first is a tendency for states which engage in systematic state violence to promote a monolithic sense of cultural identity (e.g. the project of the architects of the Turkish Republic). A supposedly indivisible 'imagined community’ (Anderson 1991) defines itself through exclusion of minorities whose claims to recognition and respect threaten the integrity of the monolith. When those claims take the form of active resistance against the state then clear ideological enemies are defined and the state may engage in a dehumanization process which excludes those enemies from the 'universe of obligation' (Fein 1990) within which ordinary moral rules apply. Monolithic cultures are frequently authoritarian in character and those agents of the state most likely to rise to its defence are found to be attracted to far right wing and fascist ideologies (Staub 1989).

A second theme that emerges clearly from the psychological research is that most torturers and purveyors of state terror, who are for the most part psychologically 
normal, require training, often of a very brutal and brutalizing nature, to counter long held socialized norms against the use of cruelty (Haritos-Fatouros 1988; Gibson 1990). Specialized elite units, such as those to which virtually all torturers of the Greek and Brazilian regimes belonged (Gibson and Haritos-Faturos 1986; Huggins et al. 2002) also appear to be essential.

The literature reveals, thirdly, that even when states portray torture and terror as essential to combat perceived threats to social order, there is a recognition on the part of state agents that this violence stands outside the bounds of political legitimacy (Cohen 1981; Green and Ward 2004).

Denial, of the various kinds analysed by Cohen (2001) is a ubiquitous response on the part of states whose wrongdoing is exposed. This is closely allied to neutralization (Sykes and Matza 1957), the difference being that neutralization occurs before or during the event rather after it. Techniques of neutralization enable perpetrators or instigators of state crime to make radical departures from conventional moral norms appear justifiable or excusable (Cohen 2001b; Alvarez 2010). New research is revealing exactly how states and corporations mobilize significant legal, financial and human resources, to conceal their illicit practices from public scrutiny. MacManus (2015) refers to a dialectical interplay between civil society condemnation and exposure of state-corporate crime and state-corporate practices of denial as a 'process of labelling and counter-labelling ... conducted in the public'. In recent decades PR companies have been 'routinely employed by governments for "crisis management", i.e. to deal with any potentially damaging public reaction to perceived state deviance or crime.' (MacManus 2015).

The economic, strategic and political interests of the major powers are also important in sustaining criminal practices and their denial, as can be seen in the cases 
of Israel and Myanmar. According to the Congressional Research Service Israel is the 'largest cumulative recipient of U.S. foreign assistance since World War II'. In 2015 the US administration funded Israel to the tune of $\$ 3.7$ billion - $\$ 3.1$ billion in direct bilateral military aid with a further $\$ 619.8$ million for 'joint' U.S.-Israel missile defence programs. US support directly enables Israel's well documented crimes in the occupied West Bank and Gaza (extrajudicial killings, ethnic cleansing, forced evictions, illegal settlements, apartheid against civilian Palestinians (Sharp 2015)).

In Myanmar, where the state is in the process of a genocidal campaign to annihilate its ethnic minority Rohingya population (Green et al 2015), the regional powers, China and India, have ignored the plight of the Rohingya as they seek to exploit Myanmar's natural resources with, for example, the Shwe gas pipeline and the Kaladan Multimodal Transit Transport Project - projects which will benefit Myanmar's rulers but not the inhabitants of the country's second poorest state (Green et al 2015).

\section{CORRUPTION, COLLUSION AND AMBIGUITY}

Apart from illegitimate state violence, the other major form of state crime is that which involves the illegitimate use of state agencies' powers over the allocation of resources. Much of corruption falls under the heading of core state crime: theft and fraud which is unambiguously illegal and generally condemned by the public. But there is also much about corruption that is legally and morally ambiguous - and its ambiguity does not necessarily make it less serious. 
In Papua New Guinea, for example, the corruption of greatest concern to local civil society activists ${ }^{4}$ is not so much the blatant scams and embezzlement for which the country is notorious (Sharman, 2012) as forms of state-corporate collusion in the (sometimes ambiguously) illegal acquisition of land rights (Ward 2016).

One of the most important insights to emerge from the economic study of corruption is the tendency of states to gravitate towards either a high or low equilibrium, i.e. a stable level of corruption (Andvig and Feldstad 2000). Levels of corruption appear to be driven by either virtuous or vicious circles. In the virtuous circle, because corruption is rare, offering a bribe is risky and accepting one carries heavy 'moral costs' (guilt and the risk of detection). In the vicious circle, because corruption is common, offering a bribe stands a good chance of success with a low risk of adverse consequences, and the costs of accepting a bribe are likely to be low. As in the case of violence, behaviour that is deviant according to one set of standards may amount to conformity to the expectations of those who can apply the most effective pressure to the individual actor. In a metaphor used by Hong Kong police officers, you can get on the bus (participate in corruption) or run alongside the bus (abstain from corruption but not interfere with it), but if you stand in front of the bus you are liable to be run over (Kutnjak Ivkovic 2005).

Corruption is important both as a major form of crime in its own right and as a factor in understanding some forms of state violence. For example, the vulnerability of certain populations to natural disasters (the 1999 Marmara earthquake, Hurricane Katrina in 2005, the Haitian earthquake, and the Pakistan floods of 2010) is directly attributable to corrupt decision-making processes and the

We draw here on Kristian Lasslett's contributions to the research mentioned in $\mathrm{n} .1$ above. 
resulting deaths can be considered a form of indirect state violence. Many states collude with criminal organizations to carry out violence as well as illicit business and numerous violent regimes rely on corrupt networks to sustain their power (see e.g. Heyman 1999; Green and Ward 2004).

At its most extreme, this contradiction between the formal rules of government and the real exercise of power manifests itself in a 'shadow state' (Reno 1995), where the legally constituted system is little more than a façade erected to secure international respectability and aid. In Weberian terms such states can be classed as 'neo-patrimonial' (Médard 2001) - patrimonialism (personal and economic ties between rulers and subordinates) is the real basis of the rulers' power, and of such domestic legitimacy as they may possess, but the formal structure of authority presents itself as a rational-legal one. Bayart et al. (1999) have discussed some extreme examples of the 'criminalization of the state in Africa', where relatively small states such as the Comoros Islands and Equatorial Guinea were largely financed by smuggling. Another extreme form of corruption is 'kleptocracy' where the theft of public resources by a ruling elite appears to be the ruling principle of the state. Examples include Liberia under (and before) Charles Taylor and Zaire under Mobutu (Schatzberg 1988).

\section{STATE CRIME AND THE ETHNOGRAPHIC TRADITION}

Given the strong Marxist antecedents informing the study of state violence and corruption, it is unsurprising that research in the field has been impelled by three main drivers: (a) the political and economic context in which these crimes take place; (b) the primacy of victims' perceptions; and (c) an intimate examination of perpetrator agency. Combined with an implicit distrust of state-produced and packaged 
knowledge researchers are thus led to rely far more on the direct testimony of victims and perpetrators and detailed examinations of political economy.

Criminology has a narrowly drawn but important tradition of ethnographic research dating back to the Chicago School of the 1920s and Robert Park's injunction to young scholars to 'go out and get your hands dirty in real research' (Park 1966: 71). A revival of criminological ethnography in the late 1990s saw the method again confined to the marginalized and familiar constituents of criminology's oeuvre (see in particular Ferrell and Hamm 1998) - and also to deviance within the police (e.g. Westley 1970; Holdaway 1982, Choongh 1997, Westmarland 2011).

Where ethnography first begins to address other state crime issues, however, is unsurprisingly within the domain, not of criminology, but of anthropology, the original home of ethnography (see for example Sluka 1999, Keenan 2009, 2013; and Jefferson and Jensen 2009). Mehmet Kurt for example, in studying notions of violence, state, religion and belonging in Turkey's Kurdish Hizbullah employed his former status as an imam to secure access and trust from his participants. Kurt examines in intimate detail the manner in which Islamic civil society has taken root in a region where ethnic identity has been the primary organizing tool against a repressive and violent state. Despite the rise of Islamic radicalization in Kurdish South East Turkey, almost all scholarly work has focused on mainstream Islamic civil society organisations (Jenkins 2008). This body of work concludes that Turkish Islamist groups have found a 'peaceful' way to compromise with the secular regime and the ruling Peace and Development Party's (AKP) political administration (Turam 2007). Kurt's research suggests this is a misleading picture of Islamism in Turkey and that Kurdish Islamist CSOs, such as Özgür-Der and Ay-Der, which have flourished in the region since at least 2005, are not only becoming increasingly radicalised, but that 
many hundreds of their members are joining the IS and Al Nusra Front in the jihadist war in Syria (Kurt 2015).

Through ethnographic field work and extensive interviews with members, leaders and supporters of Hizbullah we are not only given an insight into the workings of a rather clandestine form of 'civil society' but an explanation of why Hizbullah has proved so attractive to young Kurds and why so many of them have crossed the border into Syria to fight with Islamic State. Kurt's work captures both an Islamist response to state criminality and a source of the growth of a new kind of criminal state, Islamic State (Kurt 2016 forthcoming).

\section{NEW DATA, NEW METHODS}

The dangers and difficulties involved in researching state crime continue to foster particular forms of creative resourcefulness with regard to methodology and access. Those working on state crime are, perhaps, predisposed to seek nontraditional and alternative data sources given the guarded nature of the subject. Accepting that the state does not provide neatly packaged statistical documentation on state deviance, and given the critical framework within which these scholars work, data is necessarily sought elsewhere.

One of the most innovative methods of securing research access was conceived by the Harvard Humanitarian Initiative and its local partners in the Democratic Republic of Congo, the Centre d'Assistance Medico-Psychosociale (CAMPS). In order to interview Mai Mai militia combatants active in the southern Kivu province and heavily involved in the perpetration of sexual and other violence, lead researcher Michael van Rooyen negotiated with a commanding colonel living in the forest outside the town of southern Kivu town of Kamituga. As Kamituga was 
under the control of the Congolese National Military, researchers negotiated a 48-hour amnesty for the combatants who were then required to disarm at the entrance to the town before entering for interviews (HHI 2009:13).

A further example, drawn from one of the authors' own work, relates to negotiating access in an environment of absolute denial. In researching the genocidal processes faced by the Muslim ethnic Rohingya in Myanmar, Green and her colleagues met a wall of silence when seeking to locate Rohingya detention camps to the west of Rakhine state's capital Sittwe. The Myanmar state denies the very existence of the Rohingya identity (use of the term Rohingya is forbidden in the country), and because of the complete segregation which operates in southern Rakhine state, locating camps in the region of Mrauk U proved extremely difficult. However, with the aid of a GPS, bone rattling bicycles, a UNOCHA ${ }^{5}$ map and the air of naïve tourists it was (after several hours cycling across dry paddy fields and peasant tracks) possible to locate a Rohingya village and nearby camp and to conduct interviews and observations before being pursued by Myanmar security forces (see Green et al 2015).

While fieldwork remains the central core of data gathering there are rich sources to be plumbed beyond the academy: eyewitness accounts from reputable journalists and quality print and broadcasting media (see especially the reports and films of Egypt's Mosireen Collective, Robert Fisk, Al Jazeera's Phil Rees, and John Pilger); civil society organizations, former state agents, legal firms, and NGOs can provide a wealth of valuable and reliable data. Social media, camera phones, and web

\footnotetext{
${ }^{5}$ United Nations Office for the Coordination of Humanitarian Affairs
} 
technologies have encouraged the phenomenon of 'citizen journalism' and thereby provided a means through which civil society can reach large global audiences without recourse to traditional forms of media. Increasing numbers of human rights and advocacy groups have joined forces with citizen journalists (see especially during the Arab uprisings of 2011), encouraging them to document abuses in order to frustrate censorship and expose state repression, violence and corruption. During the Libyan uprising of February 2011 Google set up an account so that anyone in the country with a phone could call one of a range of numbers and leave a voice message about what was happening on the streets. The message was then automatically translated into a tweet in order to evade the communication blackout that Gaddafi's regime had imposed (Al Jazeera 2011). While not an immediately obvious research tool Google nonetheless provided a mechanism which allowed real time data to flow into the international public domain.

Other researchers are analyzing social media content in order to source data on events which they would otherwise be unable to study (see Saeb Kasm's work on Egypt's Mosireen Video Collective, 2016 forthcoming). For scholars of state crime these developments hold exciting promise but they must also be approached with rigorous regard to issues of data verification. Determining the provenance of human rights abuse claims through text, images and footage and ascertaining the veracity and authenticity of sources is thus opening new methodological challenges to scholars drawing on new media data.

As we saw in the section on 'mapping', reliable quantitative data on state violence are hard to come by, and scholars often have to resort to 'meta-guesstimates' arrived at by averaging out the widely varying estimates available. Some more 
sophisticated demographic techniques for estimating death rates are discussed by Bijleveld (2008). Hagan and Rymond-Richmond used data from the Darfur Atrocities Documentation Project, the US State Department's survey into genocidal processes in Sudan $^{6}$ to advance their claim that genocide had taken place in Darfur; that a criminology of genocide was required; and that such a criminology could be used to advocate against genocide (Hagan and Rymond-Richmond 2008).

A newer methodology which has a particular value for the state crime scholar exploring state terror, ethnic cleansing, war crimes, and genocide is that of satellite earth observation imagery, already pioneered in archaeology for the protection and management of cultural heritage. Researchers may hire satellite capacity in order to monitor troop or militia movements; village destruction; population displacement; and the destruction of farm and pastureland. The costs remain high but the Satellite Sentinel Project which was launched by human rights organization Not on Our Watch to monitor troop movements in Southern Sudan in 2011 has demonstrated the potential of satellite data for researching criminal state practices (http://satsentinel.org/; McGreal 2010).

Investigating crimes of powerful state agents can be difficult, harrowing, and sometimes dangerous (Schirmer 1998; Nordstrom 2004; Green 2003). One of the reasons why so few researchers venture into empirically investigating crimes committed by generals, politicians, and state officials is the assumption that access to the powerful and their criminogenic processes will be denied. Access to powerful

\footnotetext{
${ }^{6} 1,136$ eyewitnesses in refugee camps in Chad were interviewed by the research team, 'a sample large enough to be a statistically significant representation of the estimated 200,000 Darfuri refugees in Chad' Genocide Watch. www.genocidewatch.org/provinggenocidedarfur.html.
} 
perpetrators may, however (with persistence and tenacity), be less difficult to secure than imagined, as the work of many of the authors cited above demonstrates. State crime researchers tend, however, to side with those for whom change brings freedom from state abuses. In so doing state crime researchers are adopting Scheper-Hughes' notion of 'ethical orientation' in which the personal accountability of the researcher is answerable to the 'other' (Scheper-Hughes 1992: 24). This ethical orientation speaks to a commitment to justice and moral alignment with the victims of state violence and corruption, in the pursuit of truth and change.

\section{CONCLUSION}

State crime scholarship is an expanding field and one that is no longer confined to a few marginalized critical voices. It remains the case that most work on genocide, corruption, torture and other state crimes is not carried out by people who define themselves as criminologists; but criminology can provide both a meeting place for ideas deriving from other disciplines and make a distinctive contribution through its focus on rules, transgression and processes of censure.

It is over 150 years since Proal (1843: 2) began his pioneering study by quoting Seneca's observation that ' $[\mathrm{t}]$ he desire to rule and the exercise of authority teach fraud and violence'. If crime can be defined, as Gottfredson and Hirschi argued, as 'acts of force or fraud undertaken in pursuit of self-interest' (1990: 15) then criminology's recognition of Seneca's ancient insight is long overdue. Work such as Agnew's 'unified' approach - not to mention the inclusion of this chapter in the Oxford Handbook - suggests that mainstream criminology is beginning to take notice of the obvious importance of state crime, even if it does not yet occupy a place within the discipline commensurate with its scale and destructiveness. 


\section{- SELECTED FURTHER READING}

Brannigan, A. (2013), Beyond the Banality of Evil: Criminology and Genocide.

Oxford: Oxford University Press.

Chambliss, W., Michalowski, R., and Kramer, R. (eds) (2010), State Crime in the Global Age, Cullompton: Willan Publishing.

Cohen, S. (2001), States of Denial: Knowing About Atrocities and Suffering, Cambridge: Blackwell.

GreEn, P. and WARD, A. (2004), State Crime: Governments, Violence and Corruption, London: Pluto Press.

Huggins, M.K., Haritos-Fatouros, M., and Zimbardo, P.G. (2002), Violence Workers: Police Torturers and Murderers Reconstruct Brazilian Atrocities, Berkeley: University of California Press.

\section{- REFERENCES}

Agnew, R. (2011). Toward a Unified Criminology. New York: NYU Press.

Al JAZEERA (2011), 'How Did Egypt become so Corrupt?', Inside Story aired 7

February

2011.www.aljazeera.com/programmes/insidestory/2011/02/201128111236245

847.htmlhttp://english.aljazeera.net/ palestinepapers/ 2011/01/

201112214310263628.html.

Alvarez, A. (2010), Genocidal Crimes, London: Routledge.

AMNESTY INTERNATIONAL (2015), Amnesty International report 2014: the state of the world's human rights.http://thereport.amnesty.org/facts-and-figures. https://www.amnesty.org/en/latest/news/2015/02/annual-report-201415-factsand-figures/ 
ANDERSON, B. (1991), Imagined Communities: Reflections on the Origin and Spread of Nationalism, London: Verso.

Andvig, J.C. and Feldstad, O-H. (2000), Research on Corruption: A Policy Oriented Survey, Oslo: Chr. Michelsen Institute and Norwegian Institute for International Affairs.

BAyART, J-F., Ellis, S., and Hibou, B. (1999), The Criminalization of the State in Africa, Oxford: James Currey.

Beyerle, S. (2014), Curtailing Corruption: People Power for Accountability \& Justice, Boulder: Lynne Rienner.

BiJleveld, C. (2008), 'Missing Pieces. Some Thoughts on the Methodology of the Empirical Study of International Crimes and other Gross Human Rights Violations', in A. Smeulers and R. Haveman (eds), Supranational Criminology: Towards a Criminology of International Crimes, Antwerp: Intersentia.

Brannigan, A. (2013), Beyond the Banality of Evil: Criminology and Genocide. Oxford: Oxford University Press.

Burger, J.M. (2009), 'Replicating Milgram: Would People Still Obey Today?', American Psychologist 64(1): 1-11.

CARson, W. G. (1979), 'The Conventionalisation of Early Factory Crime’, International Journal for the Sociology of Law 7: 37-60.

Choongh, S. (1997), Policing as Social Discipline, Oxford: Clarendon Press.

CoHEN, S. (1981), 'Footprints on the Sand: A Further Report on Criminology and the Sociology of Deviance in Britain', in M. Fitzgerald, G. McLennan, and J. Pawson (eds), Crime and Society: Readings in History and Theory, London: Routledge \& Kegan Paul. 
— (2001b), States of Denial: Knowing About Atrocities and Suffering, Cambridge: Blackwell.

(2001c), 'Memory Wars and Peace Commissions', Index on Censorship, 30(1): $38-48$.

Congressional ReSeArch Service (2009) Israel and Hamas: Conflict in Gaza (2008-2009) <https://www.fas.org/sgp/crs/mideast/R40101.pdf>

DeSwaAn, A. (2001), 'Dyscivilization, Mass Extermination and the State', Theory, Culture \& Society, 18(2-3): 265-76.

Doyal, K., \& Gough, I. (1981). A Theory of Human Need. Basingstoke: Macmillan. DurKheIM, E. (1952). Suicide, trans. J. A. Spaulding and G. Simpson. London: Routledge \& Kegan Paul.

Elias, N. (2000), The Civilizing Process, Oxford: Blackwell.

FEIn, H. (1990), 'Genocide: A Sociological Perspective', Current Sociology, 38: 1111.

FEITLOwITZ, M. (1998), A Lexicon of Terror: Argentina and the Legacies of Terror, Oxford: Oxford University Press.

Ferrell, J. and HAMM, M. (1998), Ethnography at the Edge: Crime, Deviance and Field Research, Boston: Northeastern University Press.

FESTINGER, L. (1962), A Theory of Cognitive Dissonance, Stanford: Stanford University Press.

FRANSSEN, R. and MACMANUS, T. (2012 forthcoming), 'NGOs and Justice: researching state crime in West Africa', State Crime Vol.1(1) No. 2.

FRIEDRICHS, D. O. (1995), 'State Crime or Governmental Crime: Making Sense of the Conceptual Confusion', in J.I.Ross (ed.), Controlling State Crime: An Introduction, New York: Garland. 
Gellner, W.A. and Toch, H. (eds) (1996), Police Violence, New Haven, CT: Yale University Press.

GEWIRTH, A. (1978), Reason and Morality, Chicago: University of Chicago Press.

GiBSON, J.T. (1990), 'Factors contributing to the Creation of a Torturer', in P. Suedfeld (ed.), Psychology and Torture, New York: Hemisphere.

— and Hartos-Fatouros, M. (1986), 'The Education of a Torturer', Copenhagen: Denmark Torture Rehabilitation Centre, RCT, 16 November: 50-8.

GLuECK, S. H. (1946), The Nuremberg Trial and Aggressive War, New York: Knopf. Goldstone, R. (2009), Human Rights in Palestine and Other Occupied Arab Territories: Report of the UN Fact-Finding Mission on the Gaza Conflict. www2.ohchr.org/english/bodies/hrcouncil/specialsession/9/docs/UNFFMGC_ Report.PDF.

GotTfredson, M. R. and HiRsCHI T. (1990), A General Theory of Crime. Stanford, CA: Stanford University Press.

GramsCI, A. (1971), Selections from the Prison Notebooks, London: Lawrence \& Wishart.

Graziano, F. (1992), Divine Violence. Spectacle, Psychosexuality and Radical Christianity in the Argentine 'Dirty War', Boulder: Westview.

GreEn, P. (1990), The Enemy Without: Policing and Class Consciousness in the Miners' Strike, Milton Keynes: Open University Press.

_ (2012 forthcoming), 'Wikileaks for state crime scholars: the Ankara cables', State Crime, Vol. 1(2).

— and WARD, T. (2000), 'State Crime, Human Rights and the Limits of Criminology', Social Justice 27, 101-15. 
and — (2004), State Crime: Governments, Violence and Corruption, London:

Pluto Press.

— and — (2008) 'Torture and the Paradox of State Violence' in B. Clucas, G.

Johnstone and T. Ward (eds.) Torture: Moral Absolutes and Ambiguities.

Baden-Baden: Nomos.

— and - (2009), 'Violence and the State' in R. Coleman, J. Sim, S. Tombs and D. Whyte (eds.) State, Power, Crime. London: Sage. and (forthcoming) Civil Resistance to State Crime. London: Routledge.

Greenberg, K.J. and Dratel, J.L. (eds) (2005), The Torture Papers: The Road to Abu Ghraib, Cambridge: Cambridge University Press.

GrewCOCK (2010), Border Crimes: Australia's “War” On Illicit Migrants, Annandale: Federation Press.

Hagan, J. (2003), Justice in the Balkans: Prosecuting War Crimes in the Hague Tribunal, Chicago: University of Chicago Press.

and RYMOND-RICHMOND, W. (2008), Darfur and the Crime of Genocide, Cambridge Studies in Law and Society, New York: Cambridge University Press.

HARDT, M. and Negri, A. (2000), Empire, Cambridge, MA: Harvard University Press.

HARITOS-FATOuROS, M. (1988), 'The Official Torturer: a learning model for obedience to an authority of violence', Torture (RCT) 26: 69-97.

— (2003), The Psychological Origins of Institutionalized Torture, London: Routledge.

Harriott, A. (2000), Police and Crime Control in Jamaica: Problems of Reforming Ex-Colonial Constabularies, Kingston: University of the West Indies Press. 
HARVARD Humanitarian INITIATIVE (HHI) (2009), Characterizing Sexual Violence in the Democratic Republic of the Congo: Profiles of Violence, Community Responses, and Implications for the Protection of Women, August 2009, Final Report for the Open Society Institute (Cambridge, MA: Harvard Humanitarian Initiative and Open Society Institute, 2009). Available at www.hhi.harvard.edu/images/resources/reports/final report for the open society institute-1.pdf.

Hersh, S. N. (2005), Chain of Command, London: Penguin.

Heyman, J. M. (ed.) (1999), States and Illegal Practices, Oxford: Berg.

Hillyard, P. (1993), Suspect Community, London: Pluto.

—. and PerCy-Smith, J. (1988), The Coercive State, London: Pinter.

— and Tombs, S. (2007), 'From “Crime” to Social Harm?', Crime, Law \& Social Change, 48: 9-25.

Hinton, M. S. (2006), The State in the Streets: Police and Politics in Argentina and Brazil, Boulder: Lynne Rienner.

— and Newburn, T. (2008), Policing Developing Democracies, Abingdon: Routledge.

Holdaway, S. (1982), Inside the British Police, Oxford: Blackwell.

Home OfFICE (2011) Research and Development Statistics 2011 http://rds.homeoffice.gov.uk/rds/pubsintro1.html.

Hoofnagle, K. (2011). 'Burundi: A History of Conflict and State Crime'. In D. L. Rothe and C. W. Mullins (eds.), State Crime: Current Perspectives (pp. 142161). New Brunswick: Rutgers University Press. 
Huggins, M.K., Haritos-Fatouros, M., and Zimbardo, P.G. (2002), Violence

Workers: Police Torturers and Murderers Reconstruct Brazilian Atrocities, Berkeley: University of California Press.

INTERNATIONAL STATE CRIME INITIATIVE (ISCI) www.statecrime.org.

IRAQ BODY COUNT (2011), www.iraqbodycount.org/database/.

JACKSON, R. (2005), Writng the War on Terrorism: Language, Politics and CounterTerrorism, Manchester: Manchester University Press.

JAMIESON, R. (1998), 'Towards a Criminology of War in Europe', in V. Ruggerio, N. South, and I. Taylor (eds), The New European Criminology, London: Routledge.

JefFerson, T. (1990), The Case Against Paramilitary Policing, Milton Keynes: Open University Press.

Jenkins, G. (2008) Political Islam in Turkey Runnig West Heading East. New York: Palgrave Macmillan

Jensen, S. and JeFFERSON, A. (2009), State Violence and Human Rights: State Officials in the South, London: Routledge.

JofFe, G. (2011), 'Libya Past and Present?', English Aljazeera, http://english.aljazeera.net/indepth/opinion/2011/02/201122412934486492.ht $\underline{\mathrm{ml}}$.

KASM, S. (2017 forthcoming)

KALdOR, M. (2006), New and Old Wars, 2nd edn, Cambridge: Polity.

KAUZlarich, D. and KrAMER, R.C. (1998), Crimes of the American Nuclear State: At Home and Abroad, Boston: Northeastern University Press.

KeEnAN, J. (2013) The Dying Sahara: US Imperialism and Terror in Africa, London: Pluto Books 
. (2009) The Dark Sahara: America's War on Terror in Africa, London: Pluto Books

Kelman, H. C. and Hamilton, V. L. (1989), Crimes of Obedience, New Haven: Yale University Press.

KEnNEDY, D. (2006), Of War and Law, Princeton: Princeton University Press.

KURT, M. (2017 ForTHCOMING) Hizbullah in Turkey: Religion, Violence and Belonging, London: Pluto Press

Kutnjak Ivkovic, S. (2005), Fallen Blue Knights: Controlling Police Corruption, New York: Oxford University Press.

Lasslett, K. (2010), 'Scientific Method and the Crimes of the Powerful', Critical Criminology 18: 211-28.

LYNCH, M. J. AND STRETESKY, P. B. (2010) 'Global Warming, Global Crime: A Green Criminological Perspective' in R. White (ed.) Global Environmental Harm: Criminological Perspectives. Cullompton: Willan.

McGReal, C. (2010), 'George Clooney and Google launch satellite plan to avert Sudan violence', Guardian, 29 December.

MARCHAK, P. (1999), God's Assassins: State Terrorism in Argentina in the 1970s, Montreal: McGill-Queen's University Press.

MÉDARD, J-F. (2001), 'Corruption in the Neo-patrimonial States of Sub-Saharan Africa', in M. Johnston and A. J. Heidenheimer (eds), Political Corruption: Contexts and Consequences, New Brunswick: Transaction.

MilgRAM, S. (1974), Obedience to Authority, New York: Harper \& Row.

Mullins, C. W. (2011), 'The Current Status and Role of the International Criminal Court', in D. L. Rothe and C. W. Mullins (eds), State Crime: Current Perspectives, New Brunswick: Rutgers University Press. 
and Rothe, D. (2008) Blood, Power and Bedlam: Violations of International

Criminal Law in Postcolonial Africa. New York: Peter Lang.

Nordstrom, C. (2004), Shadows of War: Violence, Power, and International

Profiteering in the Twenty-First-Century, Berkeley, Los Angeles, London:

University of California Press.

PARK, R. E. (1966), 'Unpublished Statement made by Robert E. Park and Recorded by Howard Becker while a Graduate Student at Chicago in the Twenties', in J.

C. McKinney (ed.), Constructive Typology and Social Theory, New York: Appleton-Century-Crofts.

ProAl, L. (1898), Political Crime, London: T. Fisher Unwin.

Punch, M. (1985), Conduct Unbecoming: the Social Construction of Police Deviance and Control, London: Taylor and Francis.

— (2010), Shoot to Kill: Police Accountability, Firearms and Fatal Force, Bristol: Policy Press.

(2012) State Violence, Collusion and the Troubles. London: Pluto Press.

RAFTER, N. (2016), The Crime of All Crimes: Toward a Criminology of Genocide. New York: New York University Press.

Reno, W. (1995), Corruption and State Politics in Sierra Leone, Cambridge: Cambridge University Press.

Rothe, D. L. (2009), State Criminality: The Crime of All Crimes. Lanham, MD: Lexington.

Rummel, R. J. (n.d.), '20 ${ }^{\text {th }}$ Century Democide’, www.hawaii.edu/powerkills/20TH.HTM and www.hawaii.edu/powerkills/DBG.CHAP2.HTM. 
RuSSELl, N. AND GREgORY, R. (2015) 'The Milgram-Holocaust Linkage: Challenging the Present Consensus' State Crime 4(2):128-153.

SchAtZBERG, M. G. (1988), The Dialectics of Oppression in Zaire, Bloomington: Indiana University Press.

SCHEPER-Hughes, N. (1992), Death without Weeping, Berkeley: University of California Press.

SCHIRMER, J. (1998), The Guatemalan Military Project, Philadelphia: University of Pennsylvania Press.

SCRAton, P. (1985), The State of the Police. London: Pluto.

— and CHADwICK, K. (1991), 'The Theoretical and Political Priorities of Critical Criminology', in K. Stenson and D. Cowell (eds), The Politics of Crime Control, London: Sage.

SHARLACH, L. (1999) 'Gender and Genocide in Rwanda: Women as Agents and Objects of Genocide', Journal of Genocide Research 1(3): 387-399.

Sharman, J. (2012) Chasing Kleptocrats' Loot: Narrowing the Effectiveness Gap. Oslo: Christian Michelsen Institute.

SHARP, J. 'U.S. Foreign Aid to Israel,' The Congressional Research Service's report June 10, 2015.

SLuKA, J. (ed.) (1999) Death Squad: The Anthropology of State Terror, Philadelphia: University of Pennsylvania Press.

SMEulers, A. (2008), 'Perpetrators of International Crimes: Towards a Typology', in A. Smeulers and R. Haveman (eds), Supranational Criminology: Towards a Criminology of International Crimes, Antwerp: Intersentia. 
Staub, E. (1989), The Roots of Evil: The Origins of Genocide and Other Group

Violence, Cambridge: Cambridge University Press.

Stockholm International PEACE RESEARCh Institute (2015), Recent Trends in Military Expenditure. Stockholm: SIPRI

[http://www.sipri.org/research/armaments/milex/recent-trends]

Straus, S. (2006), The Order of Genocide: Race, Power and War in Rwanda, Ithaca: Cornell University Press.

SYKES, G. and MATZA, D. (1957), 'Techniques of Neutralization: a Theory of Delinquency', American Sociological Review, 22: 664-70.

SYRIANS For Human Rights (2015) 'Death Toll'

http://sn4hr.org/blog/category/victims/death-toll/

Syrian NETwOrk For Human RIGHTS (2016), Syria: Confronting Fragmentation!

SCPR-report-Confronting-fragmentation-2015-EN.pdf

TURAM, B. Between Islam and the State: The Politics of Engagement. Stanford: Stanford University Press, 2007.

WARD, T. (2004), 'State Harms', in P. Hillyard, C. Pantazis, S. Tombs, and D. Gordon (eds), Beyond Criminology: Taking Harm Seriously, London: Pluto.

— (2005), 'State Crime in the Heart of Darkness', British Journal of Criminology, 45: 434-45.

(2016) 'Civil Society Perspectives on Corruption and Human Rights: The Case of Papua New Guinea' in L. Weber, E. Fishwick and M. Marmo (eds.) The Routledge International Handbook of Criminology and Human Rights. London: Routledge.

Weber, M. (1970), 'Politics as a Vocation', in H. Girth and C. Wright Mills (eds), From Max Weber: Essays in Sociology, London: Routledge \& Kegan Paul. 
Westmarland, L. (2011) 'Blowing the Whistle on Police Violence: Gender, Ethnography and Ethics' British Journal of Criminology 41: 523-535.

Westley, W. A. (1970), Violence and the Police, Cambridge, MA: MIT Press.

WheAtley, Col. K. D. (2006), 'Strategic Lawyering: Realizing the Potential of Military Lawyers at the Strategic Level', Army Lawyer, 1-16.

Whyte, D. (2007), 'The Crimes of Neo-Liberal Rule in Occupied Iraq', British Journal of Criminology, 47(2): 177-195.

_ (2010), 'The neo-liberal state of exception in occupied Iraq', in W. Chambliss and R. Michalowski (eds), State Crime in the Global Age, Collumpton: Willan.

— (2012), 'Researching the Worlds of State-Corporate Elites', State Crime, 1(1).

WiKILEAKS (2011), Cablegate: 250, 000 US Embassy Diplomatic Cables http://213.251.145.96/index.html.

World Health Organization (2002), World Report on Violence and Health. www.who.int/violence_injury_prevention/violence/world_report/en/. 